\title{
Reenacting the Equal Access to Justice Act: A Proposal for Automatic Attorney's Fee Awards
}

In 1980, Congress passed the Equal Access to Justice Act ${ }^{1}$ as an innovative experiment ${ }^{2}$ in using attorney's fees awards toward a new and pressing end-that of ensuring administrative accountability. ${ }^{3}$ Congress feared that parties with limited resources were too often being coerced into compliance with government orders, discouraged by the high costs of litigation $^{4}$ and the far greater resources behind government litigators ${ }^{5}$ from bringing even the most meritorious suits against administrative agencies. ${ }^{6}$ Allowing such governmental actions to go unchallenged, Congress feared,

1. Pub. L. No. 96-481, tit. II, $\S \S 201-208,94$ Stat. 2321, 2325-30 (1980) (codified as amended at 28 U.S.C. $\S 2412$ (d)(1)(A) (1982) and 5 U.S.C. $\S 504$ (1982)) [hereinafter cited as EAJA or the Act]. The Act contains provisions authorizing attorney's fee awards in both judicial proceedings, 28 U.S.C. $\S 2412$ (1982), and in administrative actions, 5 U.S.C. $\S 504$ (1982). Awards in judicial proceedings are governed by two main provisions: $\S 2412(\mathrm{~b})$, which waives the government's sovereign immunity to fee awards and makes it liable for fees to the same limited extent that any private party would be, 28 U.S.C. $\S 2412$ (b) (1982); and $\S 2412$ (d)(1)(A), which authorizes fee awards against the government in a broad range of additional cases, $i d$. $\S 2412(\mathrm{~d})(1)(\mathrm{A})$. This Note is exclusively concerned with $\S 2412(\mathrm{~d})(1)(A)$.

2. The Act was enacted with a three-year "sunset" attached to its central provision. See EAJA, supra note 1, at $\S 204$ (d)(5)(e) (effective October $1,1984, \S 2412$ (d) is repealed).

3. In establishing a general presumption in favor of an award in a broad class of cases, $\S$ 2412 (d)(1)(A) represents a dramatic departure from both the common law and previous congressional practice. At common law, the "American rule" has dictated that fee awards be used against private parties only for the limited purposes of punishing bad faith conduct and distributing the costs of a suit among its beneficiaries, and doctrines of sovereign immunity have insulated the government from any fee liability at all in the absence of specific statutory authorization. See Alyeska Pipeline Service Co. v. Wilderness Society, 421 U.S. 240, 257-59, 267-68 (1975). While Congress has authorized fee awards in many additional cases, it has done so by adopting fee-shifting provisions tied to specific statutory policies deemed particularly important. E.g., the Freedom of Information Act, 5 U.S.C. § 552(a)(4)(E) (1982); the Voting Rights Act Amendments of 1975, 42 U.S.C. $\$$ 19731.(e) (1982); the Givil Rights Attorney's Fee Awards Act of 1976, 42 U.S.C. $§ 1988$ (1982); see also Equal Access to Justice Act of 1979: Hearings on S.265 Before the Subcomm. on Improvements in Judicial Machinery of the Senate Comm. on the Judiciary, 96th Cong., 1st Sess. 46 (1979) (statement of Raymond S. Calamaro, Deputy Ass't Attorney General, Office of Legislative Affairs, Dep't of Justice) (noting previous "categorical" approach to fee-shifting, under which Congress provided for fee awards only where the suit "advances a strong congressional policy"). Thus, although the number of provisions authorizing fee awards against the government has almost doubled since 1960, Derfner, The True American Rule: Drafting Fee Legislation in the Public Interest, 2 W. NEW ENG. L. REv. 251, 252 (1979), the vast majority of these provisions have been limited to cases brought under a single statute, or section of a statute, id. at 254 n.12.

4. See EAJA, supra note 1 , at $\S 202$ (a) (statement of congressional findings); S. REP. No. 1005, Pt. 1, 96th Cong., 2d Sess. 7 (1980).

5. See EAJA, supra note 1 , at $\S 202(\mathrm{~b})$ (statement of congressional findings); H.R. REP. No. 1418, 96th Cong., $2 d$ Sess. 5-6, reprinted in 1980 U.S. Code Cong. \& AD. News 4984, 4984.

6. Congress was particularly concerned with the existing deterrents because of its perception that the incidence of agency abuses was significant. See, e.g., Equal Access to Courts: Hearings on $S$. 2354 before the Subcomm. on Improvements in Judicial Machinery of the Senate Comm. on the 
would only increase the danger that agencies would act arbitrarily, already a serious threat in an age of rapidly expanding administrative regulation. ${ }^{7}$ Thus, the prospect of fee awards for victorious private parties in suits against the government was intended to act as both an incentive to such challenges ${ }^{8}$ and a disincentive to unreasonable governmental actions in the first instance. ${ }^{\ominus}$

In keeping with these ambitious purposes, the Act was given broad application, extending to virtually any civil case in which the government loses. ${ }^{10}$ The rule chosen to govern fee-shifting, however, was far narrower, and adopted a compromise "substantially justified" standard under which the government can avoid fee liability if it can prove that its "position" was "substantially justified" or that "special circumstances" would make an award unjust. ${ }^{11}$ Convinced, after three years of operation under this standard, that the need for such legislation had been proven by experience, Congress passed a bill to make the Act permanent law in October, 1984. ${ }^{12}$ Despite legislative and popular support for the bill, however, the

Judiciary, 95th Cong., 2d Sess. 10 (1978) (statement of Sen. Nelson) (describing as one of the "greatest threats" facing our system today the "excessive, arbitrary, nitpicking regulation and harrassment of small businesses and individuals by government burcaucrats").

7. See H.R. ReP. No. 1418, supra note 5, at 9-10. Congress perceived a "public interest" in encouraging parties to vindicate their rights against unreasonable governmental actions. $I d$. at 10 .

8. See EAJA, supra note $1, \S 202$ (c)(1) (statement of congressional purpose).

9. See H.R. REP. No. 1418, supra note 5, at 12 . Congress anticipated that by giving those subject to regulations the incentive to challenge them, the Act would "allow the agencies of regulation to be regulated by those affected." 125 CoNG. REc. 1437 (1979) (remarks of Sen. Domenici). It hoped that the prospect of fee awards would force government litigators to carefully evaluate each case before proceeding. See, e.g., H.R. REP. No. 1418, supra nate 5, at 14; S. REP. No. 1005, supra note 4, at 7 (without the prospect of fee awards, the government does not have "the economic incentive or disincentive to closely evaluate the reasonableness of its case before proceeding"). It also hoped that repeated awards in an area would induce the agencies to institute improvements in their internal machinery. See, e.g., id. at 8; H.R. REP. No. 1418, supra note 5, at 14.

10. The provision explicitly excludes only tort suits and cases in which fees are already authorized under other statutes, and Congress specifically intended that constitutional torts be included. See H.R. REP. No. 1418 , supra note 5 , at 18 . The Act's coverage has been limited only slightly by the subsequent exclusion of cases before the Tax Court, which are now covered by a separate provision enacted by the Tax Equity and Fiscal Responsibility Act of 1982, see 26 U.S.C. \$ 7430 (1982), and by judicial rulings that cases before boards of contract appeals are likewise not included. Fidelity Construction Co. v. United States, 700 F.2d 1379, 1385-87 (Fed. Cir. 1983), cert. denied, 104 S. Ct. 97 (1983).

11. The relevant section provides in full:

Except as otherwise specifically provided by statute, a court shall award to a prevailing party other than the United States fees and other expenses, in addition to any costs awarded pursuant to subsection (a), incurred by that party in any civil action (other than cases sounding in tort) brought by or against the United States in any court having jurisdiction of that action, unless the court finds that the position of the United States was substantially justified or that special circumstances make an award unjust.

28 U.S.C. $\S 2412$ (d)(1)(A) (1982).

12. H.R. 5479, 98th Cong., 2d Sess., 130 Cong. Rec. S14378-88 (daily ed. Oct. 11, 1984), passed by Congress on October 11, 1984, would have made the Act permanent with a few minor modifications, including an increase in eligibility limits, a provision for interest on awards, and clarification of the deadline for filing fee applications. The most significant change would have been a provision further defining the "position" of the United States. See Congress Renews Attorney's Fee 
President pocket-vetoed this initiative in November. ${ }^{13}$ Reconsideration of the bill is certain to be part of the legislative agenda in $1985 .^{14}$

This Note argues that experience under the Act demonstrates that while the concerns which prompted its passage remain vital, the "substantially justified" standard chosen to implement the Act's broad purposes does not go far enough. It proposes that Congress enact a permanent version of the law, replacing the "substantially justified" standard with an automatic fee-shifting provision under which the fee inquiry would be limited to whether the private party prevailed, and on what claims. Such a standard would far better serve the Act's purpose of encouraging private parties to challenge unreasonable governmental actions, while also adequately protecting the government enforcement interests that Congress initially sought to accommodate in adopting a nonautomatic standard.

\section{The "Substantially Justified" Standard: Practical and Conceptual Problems}

In practice, cases decided under the Act reveal that congressional fears of agency abuses were well-founded, ${ }^{15}$ and that the huge disparity in resources between the government and certain private parties may indeed create deterrents to suits. ${ }^{16}$ At the same time, however, controversies over

Law, 42 Cong. Q. WeEkLy Rep. 2624 (1984).

13. See Equal Access Reauthorization Pocket Vetoed by President, 42 Cong. Q. WeEkLy ReP. 2964 (1984) (reprinting letter of disapproval).

14. Not only do the sponsors of the 1984 legislation intend to bring it before Congress again in 1985 , but the President has avowed his intention to make passage of a modified bill a high legislative priority in the coming session. See id.

15. Examples of abusive administrative practices range from decisions impacting on the lives of single citizens, e.g., United States v. Pomp, 538 F. Supp. 513 (M.D. Fla. 1982) (IRS not substantially justified in suit, dismissed with prejudice, to collect penalty from defendant where record showed that it had determined prior to filing complaint that defendant was not liable), to those affecting thousands, e.g., Underwood v. Pierce, 547 F. Supp. 256 (C.D. Cal. 1982) (government not substantially justified where plaintiffs obtained a $\$ 60$ million settlement from HUD on behalf of class of low-income tenants for HUD's refusal to implement subsidy program for low-income federal housing project tenants).

16. An examination of the government's opposition to fee awards in litigation under the Act provides a striking example of its ability to discourage private parties from challenging governmental actions by litigating an issue vigorously, thereby significantly raising the costs to private parties of pursuing even legitimate claims. The government has repeatedly raised every conceivable argument against an award, even where it has been unable to convince a single court of the merits of its argument and even where its arguments are contrary to the clear legislative intent. See, e.g., Grand Boulevard Improvement Ass'n v. City of Chicago, 553 F. Supp. 1154, 1157 (N.D. Ill. 1982) ("The government . . . is attempting to protect its purse strings by consistently arguing, so far unsuccessfully, that the Act cannot possibly mean what it says."). Moreover, the government has not only contested every fee issue, but has also appealed most of the adverse trial court decisions. See Report by the Director of the Admin. Office of the U.S. Courts on Requests for Fees and Expenses Under the Equal Access to Justice Act of 1980, July 1, 1982 through June 30, 1983, at 3 (Sept. 23, 1983) [hereinafter cited as AO Report]. Governmental opposition is clearly the primary cause of the extensive litigation over many of the Act's terms, and may also be a major reason for the remarkably low number of fee applications. See infra note 18. The "intransigence" of government lawyers, who "waste public money by unnecessary and unjustified briefing and argument over points they must know will be unsuccessful," has been cited as a major reason for the excessive time spent litigating fee 
the Act's application have seriously impeded the development of an effective fee incentive. Gonfusion has surrounded virtually every term used in the statute, ${ }^{17}$ and the number of fee applications has been strikingly low, given the tremendous volume of cases covered by the Act. ${ }^{18}$ Most significantly, courts have found it extremely difficult to provide any meaningful content for the "substantially justified" standard that governs fee-shifting under the Act.

\section{A. Congressional Failure to Define "Substantially Justified"}

At the outset, courts applying the Act have had difficulty determining when to award fees because of a central flaw in the Act's legislative history: Congress adopted the "substantially justified" standard without ever adequately defining it. The term is not a carefully crafted term of art, but rather a conscious legislative compromise, designed as an "acceptable middle ground" between automatic fee-shifting and the bad faith standard

issues under the EAJA. Rawlings v. Heckler, 725 F.2d 1192, 1196-97 (9th Cir. 1984) (Burns, J., concurring in part and dissenting in part).

17. There has been confusion in the case law over such issues as whether fees are to be awarded in pending cases for work done before the Act's effective date, see Underwood v. Pierce, 547 F. Supp. 256, 260-61 (C.D. Cal. 1982) (relying on analogous statutes to apply the Act retroactively); when parties have "prevailed," compare McGill v. Secretary of HHS, 712 F.2d 28 (2d Cir. 1983) (party who succeeds in having case remanded for taking of additional evidence has not yet prevailed on disability claim), cert. denied, 104 S. Ct. 1420 (1984) with Ceglia v. Schweiker, 566 F. Supp. 118, 121-22 (E.D.N.Y. 1983) (order of remand for new hearing sufficiently central to case to justify an award); what parties can "incur" fees, see Hornal v. Schweiker, 551 F. Supp. 612, 616-17 (M.D. Tenn. 1982) (parties represented without charge may "incur" fees within meaning of Act); and what cases are excluded by virtue of an existing fee-shifting provision, see Ocasio v. Schweiker, $540 \mathrm{~F}$. Supp. 1320 (W.D.N.C. 1982) (fees not precluded in social security cases by virtue of $\S 406(b)(1)$ of Social Security Act, which governs contingency fee arrangements).

18. At the time the Act was passed, the Congressional Budget Office (CBO) estimated that the United States would lose 11,800 cases a year. H.R. REP. No. 1418, supra note 5, at 22 . However, there was a total of only 177 petitions decided under $\S 2412$ in the first 21 months of the Act's operation. AO Report, supra note 16, at 2-4. Of these petitions, only 63 ultimately resulted in awards. Id. This represents a mere fraction of congressional estimates of the number of awards that would be made. The CBO estimate, for example, was that awards would be made in approximately 3,500 cases in 1982 and 3,700 cases in 1983. H.R. REP. No. 1418, supra note 5, at 22. Similarly, the Justice Department estimated that the government would lose $15-25 \%$ of the cases it litigates cach year, and that awards would be made in $25 \%$ of these, S. REP. No. 253, 96th Cong., 1st Sess. 12 (1979); using the 1978 figure of 54,000 cases litigated by the government, Hearings, supra note 3, at 51 , this would yield awards in at least 2,025 cases a year. Thus the estimates exceed the actual number of awards by over a hundredfold. The low number of awards under the Act has disproved predictions of the exorbitantly high costs of such a program. These had ranged from an Office of Management and Budget (OMB) estimate of $\$ 205$ million during the first year, H.R. REP. No. 1418 , supra note 5 , at 23 , to an estimate by the Senate Judiciary Committee of $\$ 20$ million for its third year of operation (assuming that costs would decrease as a result of the Act's expected deterrent effect), $i d$. at 20 . In fact, awards totaling under $\$ 2.5$ million were made in the first 21 months (with one award accounting for $\$ 1.2$ million). AO Report, supra note 16 , at $2-4$. Thus, the estimates of the Act's cost upon reenactment in 1984 were as low as $\$ 3$ million in fiscal year 1985 , increasing to $\$ 5$ million in fiscal year 1989. S. REP. No. 586, 98th Cong., 2d Sess. 31 (1984); see also id. at 6 (citing figures and concluding that actual cost of the legislation was "approximately 1 percent of the estimated cost"). 
advocated by the Executive. ${ }^{19}$ The Senate selected the "substantially justified" standard only after the Justice Department expressed concerns about the breadth ${ }^{20}$ and potential $\cos ^{21}$ of the automatic standard originally considered. In deference to the Department's objections to a possible chilling effect on legitimate government enforcement efforts, ${ }^{22}$ it adopted a

19. H.R. Rep. No. 1418 , supra note 5 , at 14 . The bill originally considered by the Senate had provided simply that a judgment for reasonable costs and attorney's fees "shall be awarded to any party other than the United States which prevails in any civil action . . . other than an action in tort, brought by or against the United States . . . ." S. 2354, 95th Cong., 1st Sess. (1977). In contrast, the Justice Department's version would have allowed discretionary fee awards only where the prevailing party could prove that the government had acted in an "arbitrary, frivolous, unreasonable, or groundless" manner. H.R. REP. No. 1418, supra note.5, at 14. This language was drawn from the standard governing the few circumstances in which attorney's fee awards may be made to prevailing defendants in civil rights suits under Christiansburg Garment Co. v. EEOC, 434 U.S. 412 (1978). That this latter test is little more than a bad faith standard is demonstrated not only by judicial interpretations under Christiansburg Garment, but also by declarations by the Justice Department that a bad faith standard was what it intended under the Act. See Hearings, supra note 6, at 31 . As such, it would have rendered $\$ 2412$ (d)(1)(A) unnecessary, since another portion of the Act provided that the United States was to be held liable for attorney's fees "to the same extent that any other party would be liable under the common law," 28 U.S.C. $§ 2412$ (b) (1982), and would have sufficed to make the United States liable for fees where it acts in bad faith.

20. The Department of Justice objected that the bill was not "carefully tailored" to be "limited to those situations where the United States has regulated unreasonably or even where it has acted in error . . . "Hearings, supra note 6, at 36. It felt that in the great majority of litigated cases involving the United States "there is either a genuine dispute as to the facts, or the law is unclear as to the respective rights of the opposing parties, or both," and that "[i]t cannot be said that their positions are unreasonable." Id. at 30 . Under these circumstances, it would be "unfair to saddle the losing party with his opponent's attorneys' fees as a matter of course." Id. at 30-31. This argument erroneously implies that the fees would be awarded against private parties who lost as well as against the government.

21. The potential cost of the legislation was one of the Department of Justice's major objections to both an automatic fee-shifting provision and the "substantially justified" standard which was eventually adopted. Interestingly enough, its estimate of the cost of an automatic provision, which it calculated would range from $\$ 130$ to $\$ 250$ million a year for awards at the trial court level, Hearings, supra note 6, at 36, did not differ significantly from its estimate of the costs of a "substantially justified" standard, which it calculated would range from $\$ 130$ to $\$ 250$ million a year for all court cases, Hearings, supra note 3 , at 12 . In practice, total awards have been a mere fraction of these estimated cost figures. See supra note 18.

22. The Justice Department argued that an automatic fee provision "might well discourage parties with legitimate legal claims or defenses from resorting to the Courts," and that "potential litigants might be loathe to espouse novel legal theories for fear of incurring additional expenses if they did not prevail." Hearings, supra note 6 , at 31 . In its view, this would create a "chilling effect" with "serious consequences for developing areas of the law." Id. These arguments are extremely vague, and again suggest that fees will be awarded against either the government or the private party. This is not, however, the case, and it is unlikely that fee awards would deter the government from advancing novel legal theories in the same way that they would deter private parties. See infra text accompanying notes 83-85. The Justice Department also invoked its "constitutional obligation" to enforce the law. Hearings, supra note 6 , at 31 . This argument reflects the Executive's view that as a coordinate branch of government, its actions should be presumed to have been taken in good faith unless it is clearly proved otherwise; automatic fee awards, in its view, would create the opposite presumption of bad faith on the government's part. However, the Act is premised on the theory that in a bureaucracy, abusive governmental practices may result not solely through bad faith, but also through inadvertent errors or problems of unclear jurisdiction. Therefore, to the extent that the Department's objection to a chilling effect on enforcement efforts reflects the view that it is inappropriate to award fees automatically because most government actions are legitimate, rather than being based on any genuine fear of deterrence, it is directly contrary to the basic premises of the Act. 
compromise standard specifying that the court "shall award" attorney's fees to prevailing ${ }^{23}$ private parties ${ }^{24}$ in cases involving the United States, unless the government can prove that its "position" was "substantially justified" or that "special circumstances" would make an award unjust; ${ }^{25}$ this was intended as a narrower fee-shifting standard than an automatic provision. Nevertheless, in keeping with the idea of creating an incentive, it was meant to be a mandatory rather than discretionary standard, subject to two narrow exceptions from fee liability based on the legitimacy of the government's case.

Congress, however, failed adequately to define the exceptions to feeshifting which it thereby created. The legislative history reveals that Congress intended to place the burden on the government to make a "positive showing" of substantial justification, ${ }^{26}$ and to define "substantially justified" to require a "reasonable basis both in law and fact" for the government's position. ${ }^{27}$ Beyond identifying certain case dispositions which may indicate a lack of substantial justification, however, Congress did not define "reasonable," nor specify how such a showing was to be made. ${ }^{28}$ Similarly, while Congress intended the "special circumstances" clause to encompass the "novel but credible extensions and interpretations of the law

23. While awards are limited to "prevailing" parties, Congress specified that a party may prevail without a full trial on the merits, as for example by a favorable settlement, a voluntary dismissal of a complaint, or a partial victory. H.R. REP. No. 1418, supra note 5, at 11.

24. Because of the congressional intention to help parties with limited resources, there are certain income limits that must be met. However, eligible parties are defined broadly to include individuals with a net worth not exceeding $\$ 1$ million, and owners of businesses or organizations with a net worth not exceeding $\$ 5$ million or with 500 or fewer employees. 28 U.S.C. $\$ 2412$ (d)(2)(B) (1982). Under the 1984 reenactment bill, these limits would have been increased to a $\$ 2$ million figure for individuals and a $\$ 7$ million figure for businesses. See H.R. 5479, 98th Cong., 2d Sess., 130 CoNG. REC. S14387 (daily ed. Oct. 11, 1984).

25. See supra note 11 (reprinting provision in full). This standard was drawn from the Federal Rules of Civil Procedure, which make a party who wrongly resists discovery liable for attorney's fees unless the court finds that its "opposition to the motion [to compel] was substantially justified" or that special circumstances would make an award unjust. FED. R. Crv. P. 37(a)(4).

26. H.R. REP. No. 1418, supra note 5, at 13. Congress placed the burden of proof on the government for two reasons: First, it feared the "natural reluctance of courts to award fees" after so many years of operating under the American rule, $i d$. at 18; and second, it perceived that it would be far easier for the government, "which has control of the evidence," to prove the reasonableness of its action than for a private party to marshal the facts to prove that the governmental action was unreasonable. Id. at 10-11.

27. Id. at 10 .

28. Congress indicated that the court should "look closely" where there has been a judgment on the pleadings or a directed verdict, or where a prior suit on the same claim had been dismissed, since such cases "clearly raise the possibility that the Government was unreasonable in pursuing the litigation." Id. at 11. However, it stressed that there should be no presumption that the government's position was not substantially justified simply because it lost the case, nor should the government be required to establish that its decision to litigate was "based on a substantial probability of prevailing." $I d$. These latter qualifications clearly reflect the influence of the Justice Department's testimony. See supra notes 20-22. In practice, however, the cases call both into question, since there are many cases in which a government loss will logically support a presumption of unreasonableness, see infra text accompanying notes 93-95, while part of the congressional intent in passing the Act was to ensure 
that often underlie vigorous enforcement efforts," it provided no further guidance. ${ }^{29}$ Thus, the legislative compromise left the exact contours of the standard undefined, relying on the courts to supply any meaningful content. Even after three years of experience under the Act, Congress was unable, upon reconsidering it in 1984, to provide much further guidance other than to specify additional cases that lack substantial justification. ${ }^{\mathbf{3 0}}$

\section{B. Misplaced Judicial Emphasis on a "Nonautomatic" Standard}

Faced with the congressional failure to define "substantially justified" beyond describing it as a test of reasonableness-an explanation that adds little, if anything, to the language of the provision itself-courts applying the Act have often focused instead on the congressional description of the standard as a compromise. Emphasizing Congress' intention to create an intermediate standard between automatic fee-shifting and a bad faith test, these courts have carefully avoided applying the standard in any manner that would automatically lead to a fee award whenever the government loses. The problem with focusing on the nonautomatic operation of the standard, however, is that in certain important contexts even a test of substantial justification will result in virtually automatic fee-shifting. For example, under the deferential standards that characterize judicial review of most agency determinations, ${ }^{31}$ the agency will be reversed only if it acted unreasonably. Thus, almost by definition, agency action that fails cannot be viewed as "substantially justified." Similarly, in cases in which the private party has prevailed by obtaining a favorable settlement, the government has often conceded the case precisely because its initial action was unreasonable. Under these circumstances, examining the governmental action that led to the suit for its substantial justification will naturally result in a fee award-despite the congressional intention to make the test a nonautomatic one. Courts have resolved this contradiction between the

that the government indeed did not litigate against private parties without a strong case-and therefore a good likelihood of prevailing. See supra note 9.

29. H.R. REP. No. 1418, supra note 5, at 11 .

30. The Senate Judiciary Committee's report specified that the government should not be found to have been "substantially justified" where it is bound by departmental constraints to uphold a rule, where it makes a "long-shot" argument to overturn precedent, where it ignores precedent, or where it fails to comply with the Administrative Procedure Act (APA). See S. REP. No. 586, 98th Cong., 2d Sess. 12 (1984) (citing cases decided under the EAJA). However, it noted that "it may be easier to determine what is not 'substantially justified' rather than what is," id., and described the process of defining the term as "undoubtedly a case-by-case matter due to the wide disparity of factual contexts and legal issues that make up government disputes." Id. Thus, Congress recognized that the standard selected is inherently ambiguous.

31. When private parties sue to challenge agency actions, courts usually review the administrative decision under standards of review that give deference to the agency's expertise and judgment. While the deference is greatest in the area of agency fact-finding, it is also characteristic of review of many legal decisions made by agencies. See K. Davis, Administratrve Law Treatise $§ 29.09$ (Supp. 1982). 
standard's nonautomatic operation in theory and its often automatic operation in practice in several ways-both of which emphasize the legislative compromise at the cost of clarity and common sense.

\section{The "Position" of the United States}

Congress nowhere defined what "position" it intended courts to examine for substantial justification. ${ }^{32}$ However, courts interpreting the Act have recognized that the problem of defining "position" represents a fundamental problem that Congress ignored in selecting the "substantially justified" test: What will be found to be reasonable often depends on the government behavior being examined. Thus, the most important area of disagreement that has developed under the Act is an unanticipated split among the circuits as to what Congress meant when it referred to the "position" of the United States.

Courts interpreting the standard in light of the Act's broad underlying purposes have unanimously concluded that "position" refers not simply to the government's position in litigation but to whatever governmental action forced the private party into court. ${ }^{33}$ These courts have noted that if examination is limited to the government's litigation posture, it would not only insulate the agency from fee awards ${ }_{2}^{34}$ but would also undermine the idea of a fee incentive: Since a private party cannot anticipate what legal arguments the government will make, such a restrictive interpretation of "position" seriously impairs that party's ability to judge at the outset of litigation whether a fee award is likely. ${ }^{35}$

32. See Spencer v. NLRB, 712 F.2d 539, 548-49 (D.C. Cir. 1983) (Congress "failed to clearly" resolve" the issue), cert. denied, $104 \mathrm{~S}$. Ct. 1908 (1984). In government prosecutions this does not present a problem, since there is only one "position" involved-the position the government takes in the litigation. In cases reviewing agency decisions, however, or in cases originally brought against an agency in federal court, there may be several government "positions"- the government conduct that is at issue in the suit, or the arguments that the government makes in defense of that conduct. If a case is settled, the government's "position" could refer to its action that initially prompted the party to litigate, or to its behavior in settling.

33. See, e.g., Timms v. United States, 742 F.2d 489, 492 (9th Cir. 1984) ("[T]he remedial purpose of EAJA is best effectuated if we consider the totality of the circumstances present prior to and during litigation." (citing Rawlings v. Heckler, 725 F.2d 1192, 1196 (9th Cir. 1984))); NRDC v. EPA, 703 F.2d 700, 707 (3rd Cir. 1983) (the Act's "plain meaning and the intention of Congress" is to read "position" to refer to the "agency action that made it necessary for the party to file suit"); Photo Data, Inc. v. Sawyer, 533 F. Supp. 348, 352 n.7 (D.D.C. 1982) ("II]t would contradict the remedial purpose of the Act to interpret it to isolate and focus upon the reasonableness of only a single element of the government's actions, when the entire factual background may suggest a contrary conclusion.").

34. See NRDC v. EPA, 703 F.2d 700, 706-07 (3rd Cir. 1983) (analyzing only the government's litigation position "means that no matter how outrageously improper the agency action has been, and no matter how intransigently a wrong position has been maintained prior to the litigation, and no matter how often the same agency repeats the offending conduct, the statute has no application, so long as employees of the Justice Department act reasonably when they appear before the court").

35. See Moholland v. Schweiker, 546 F. Supp. 383, 386 (D.N.H. 1982) ("Obviously [the decision to seek judicial relief] is made prior to the action, and therefore will not be swayed by the potential 
Nevertheless, other judges have held that such a broad reading of "position" is inconsistent with the legislative compromise on a nonautomatic standard. $^{36}$ Analyzing the possible scenarios in which a fee application might arise, they have recognized that often the government's litigation posture will be identical with the underlying action, such as where the government initiates the case, or where it defends an agency action by arguing that it was legally correct. ${ }^{37}$ However, it is where the litigation position and the underlying action differ-such as in cases decided under deferential standards of review or in settlement cases-that applying the test to the underlying action would lead to virtually automatic fee-shifting, contrary to the legislative intent. ${ }^{38}$ Thus, these judges recognize that by reading "position" restrictively to refer solely to the government's litigation arguments, the standard can be applied nonautomatically.

The effect of such an interpretation, however, is to insulate from fee awards those very cases in which the private party is likely to have the strongest fee claims-cases in which the government declined to defend the agency action on the merits. ${ }^{39}$ Settlements provide a striking example: where a private party obtains full relief by settling his case, it is usually because the underlying governmental action was indefensible; for the same reason, however, the government's decision to settle such a case is likely to be faultless. Under these circumstances, which "position" is analyzed will directly determine the outcome of fee litigation. ${ }^{40}$ Thus, a restrictive reading of the "position" of the United States achieves nonautomatic results, but only at the cost of undermining the more basic purposes of the

that the government might not comport itself with proper adversarial etiquette.").

36. See, e.g., Ashburn v. United States, 740 F.2d 843, 849 (11th Cir. 1984); Spencer, 712 F.2d at 552; Operating Eng'rs v. Bohn, 541 F. Supp. 486, 493-96 (D. Utah 1982), affd, 737 F.2d 860 (10th Cir. 1984).

37. See Spencer, 712 F.2d at 551-52.

38. See Ashburn, 740 F.2d at 849 (to hold that "position" includes the underlying action "could result in an automatic award to plaintiffs in many cases," such as those decided under the substantial cvidence or arbitrary and capricious tests); Operating Eng'rs v. Bohn, 541 F. Supp. 486, 495 (D. Utah 1982) (court suggests that relying on underlying action would "compensate all parties successful in seeking judicial review of agency factual decisions").

39. See Stewart, Courts Debate Reach of Equal Access to Justice Act, Legal Times, May 16, 1983, at 16, col. 1 ("When the government itself is unwilling to defend its prior actions, almost by definition those actions were not substantially justified .....").

40. See, e.g., Del Mfg. Co. v. United States, 723 F.2d 980, 984-86 (D.C. Cir. 1984) (once "litigation position" theory is substituted for "underlying action" theory used by lower court, focus moves from agency's "torpor and tardiness" before litigation was initiated to government's prompt concession of case once complaint was filed, and fee award must be reversed); White v. United States, 740 F.2d 836, 850 (11th Cir. 1984) (if litigation position alone is examined, courts of appeals must reverse district court's award, which erroneously relied on both the government's litigation position and the underlying agency action); EDF v. Watt, 722 F.2d 1081 (2d Cir. 1983) (government conceded that underlying agency position was not substantially justified, but asserted substantial justification based on its "promptly" entering into settlement negotiations). 
Act-providing fee awards to victims of unreasonable governmental action.

\section{Defining "Substantially Justified" Under Deferential Standards of Review}

Other courts resolve the problem of avoiding automatic fee-shifting by allowing the "position" of the United States to include the underlying action, but manipulating the definition of "substantially justified" so that fee awards are not automatic. In cases decided under deferential standards of review, the illogic of this approach becomes particularly clear; since application of the standard to the underlying action tends naturally to result in a fee award, courts must contort even seemingly clear language to achieve nonautomatic results.

For example, under the "lack of substantial evidence" test," which is frequently applied in cases involving the government, ${ }^{42}$ the court's inquiry is limited to whether the agency's action is supported by substantial evidence in the record as a whole. As long as adequate support exists, the reviewing court will not reexamine the agency's decision. ${ }^{43}$ In such cases, it would make sense to hold that a lack of substantial evidence is equivalent to a finding of no substantial justification. ${ }^{44}$ However, this would make fee-shifting automatic in such cases. ${ }^{45}$ Thus, the courts have attempted to define "substantially justified" in other terms, making distinctions based on the amount and strength of the evidence in the record. They have held that while a simple finding of a lack of substantial evidence does not require a conclusion that the government was not substantially justified, ${ }^{\mathbf{4 6}}$ a finding that there was no evidence in the record supporting the agency decision does. ${ }^{47}$ Similarly, where there is some evidence

41. See 5 U.S.C. $\$ 706(2)(E)$ (1982) (the reviewing court shall set aside agency action, findings, and conclusions "unsupported by substantial evidence").

42. See S. Breyer \& R. Strwart, Administrative Law and Regulatory Policy 195 (1979) (describing substantial evidence test as the "dominant standard for judicial review of factual determinations by agencies").

43. See Universal Camera Corp. v. NLRB, 340 U.S. 474 (1951).

44. See Operating Eng'rs v. Bohn, 541 F. Supp. 486, 495 (D. Utah 1982) ("It is difficult for this court to perceive how action unsupported by 'substantial' evidence could be 'substantially justified."').

45. See Washington v. Heckler, 573 F. Supp. 1567, 1570-71 (E.D. Pa. 1983) (since Congress did not want automatic award of fees, it presumably intended question of substantial justification to be decided separately from decision on merits under substantial evidence test).

46. See, e.g., id. at 1571 (lack of substantial evidence does not mean that government's position "taken as a whole" lacked substantial basis); Bennett v. Schweiker, 543 F. Supp. 897, 898 (D.D.C. 1982) (lack of substantial evidence does not require concurrent finding of no substantial justification).

47. See, e.g., Jones v. Schweiker, 565 F. Supp. 52, 55-56 (W.D. Mich. 1983) (while finding of lack of substantial evidence does not automatically require fee award, where "record reveals no evidence to support" findings, government is not substantially justified in defending); Hornal v. Schweiker, 551 F. Supp. 612, 617 (M.D. Tenn. 1982) ("[W] hen there is little or no evidence supporting the government's position, the Court is obligated to award attorney fees.") (footnotes omitted). 
in the record supporting the government, but it is contradicted by overwhelming evidence to the contrary, the government may be found to have lacked substantial justification. ${ }^{48}$ Such distinctions are clearly untenable.

A similar problem arises in cases reviewed under the "arbitrary and capricious" standard. ${ }^{49}$ In these cases, which include most rulemaking proceedings, ${ }^{50}$ the standard for agency conduct is at least as stringent as under the "substantial evidence" test. Here application of the substantial justification test is even more clearly absurd, since it requires finding that the government's action, which the court has just found arbitrary and capricious, was nonetheless reasonable. ${ }^{51}$

\section{Legislative Recharacterization of the "Substantially Justified" Standard}

These cases suggest that by characterizing the "substantially justified" standard as a nonautomatic one, Congress failed to appreciate how the standard would operate in practice. This is, however, not a serious problem. In adopting the "substantially justified" standard, Congress was not so much concerned with whether it would result in automatic awards as it was with. whether the standard would chill legitimate government enforcement efforts. ${ }^{52}$ Thus, the courts' emphasis on the nonautomatic nature of the standard, rather than on the underlying interests that Congress intended to protect, is misplaced. Moreover, if these interests are considered, the resolution of a case against the government under a deferential standard or by a full settlement indicates that the agency action was most

48. See, e.g., Cole v. Secretary of HHS, 577 F. Supp. 657, 662 (D. Del. 1983) (finding government's position not substantially justified where ALJ "egregiously misbalanc[ed] the evidence"); Hornal v. Schweiker, 551 F. Supp. 612, 618 (M.D. Tenn. 1982) (finding government "totally unjustified" in relying on incomplete medical report "in light of the overwhelming contradictory medical cvidence"); see also, e.g., Guthrie v. Schweiker, 718 F.2d 104, 108 (4th Cir. 1983) (government's position will normally be justified if it relies on an "arguably defensible administrative record"); Ceglia v. Schweiker, 566 F. Supp. 118, 124 (E.D.N.Y. 1983) (where Secretary's decision was "patently unsupported by substantial evidence," government's position held not substantially justified).

49. See 5 U.S.C. $\$ 706(2)$ (A) (1982) ("the reviewing court shall hold unlawful and set aside agency action, findings, and conclusions found to be arbitrary, capricious, an abuse of discretion, or otherwise not in accordance with law").

50. See Spencer, 712 F.2d at 552.

51. Most courts simply allow fee-shifting to become automatic in this context. See, e.g., Wade v. Dole, No. 80 C 3072, slip op. (N.D. Ill. Dec. 19, 1983) ("[A] finding that the agency's action was arbitrary, capricious, or an abuse of discretion, is determinative of the private parties' right to fees."); Grand Boulevard Improvement Ass'n v. Gity of Chicago, 553 F. Supp. 1154, 1162 (N.D. Ill. 1982) ("It would be too much for the English language to bear to say that a position can be arbitrary, capricious, or an abuse of discretion but nevertheless (reasonable." "). But see Gava v. United States, 699 F.2d 1367, 1370-71 (Fed. Cir. 1983) (finding government substantially justified despite lower court's finding that its action was arbitrary and capricious).

52. While Congress described the standard as an "acceptable middle ground" between automatic fee-shifting and a bad faith standard, H.R. REP. No. 1418, supra note 5, at 14, this compromise was motivated solely by its concern for the government's fear of a "chilling effect on proper government enforcement efforts." Id. 
likely not a reasonable one-which is, in fact, why the automatic results tend to occur in the first place. Thus, it would not be inconsistent with the Act's purposes to resolve the problems created by the courts' misreading by simply defining "position" expansively and clarifying the relationship between certain review standards and a finding of substantial justification. Upon the Act's reconsideration in 1984, Congress specifically recognized this problem, and defined "position" to include both the litigation position and the underlying agency action; ${ }^{33}$ this change was cited by the President as his principal reason for vetoing the bill. ${ }^{54}$

\section{G. The Inevitable Problem of Inconsistent Definitions of "Substantially Justified"}

Even if the problems created by a misplaced judicial emphasis on the "nonautomatic" characterization of the provision were resolved, however, a far more fundamental problem with the selection of a "substantially justified" standard to create a fee incentive remains. As long as the Act covers both government prosecutions and defenses, and includes cases won by both trial and settlement, courts will be called upon to judge both litigation positions and underlying actions. At the same time, however, the case law indicates that applying a single definition to both is impossible. Thus, a "substantially justified" standard is inherently a discretionary one, which can only be applied on a case-by-case basis. ${ }^{55}$ Even more importantly, it is a grant of discretion for which it is impossible to develop any consistent standards. This suggests that the choice of such ambiguous language ${ }^{58}$ is simply incompatible with the idea of creating a fee incentive in a broad range of cases. ${ }^{57}$ This problem becomes clear by contrasting the definitions of "substantially justified" developed in cases decided under deferential review standards, discussed above, with those definitions adopted to analyze legal arguments and settlements.

53. H.R. 5479, 98th Cong., 2d Sess., 130 Cong. Rec. S14387 (daily ed. Oct. 11, 1984). Even after this legislative amendment, the standard would still have been far closer to an automatic one than to the compromise that Congress anticipated. This suggests that Congress failed to appreciate that there is in fact a close relation in many cases between a private party's having prevailed and the government's having acted unreasonably.

54. See Equal Access Reauthorization Pocket Vetoed By President, supra note 13, at 2964.

55. See Broad Ave. Laundry \& Tailoring, Inc. v. United States, 693 F.2d 1387, 1391 (Fed. Cir. 1982) ("Fixed rules cannot be established" for determining issue of substantial justification.). Congress recognized this problem upon reconsideration in 1984, but failed to recognize its implications for the standard's effectiveness. See supra note 30.

56. See Spencer, 712 F.2d at 546 (several of Act's "crucial terms are distressingly ambiguous").

57. Without clear standards, announced in advance, fee awards can only be compensatory, providing after-the-fact payments for parties who successfully challenge governmental actions. While making parties "whole" may be a desirable goal, however, it is a significantly different purpose than that of creating a fee incentive. 


\section{Evaluating Legal Arguments}

While judges deciding on fee applications in cases decided under deferential review standards must strain to define "substantially justified" without creating automatic fee-shifting, in the context of judging the government's litigation position courts have the opposite tendency of reducing the test to an "arguable" standard. In this area, the range of legal arguments that might be considered reasonable is very broad. ${ }^{58}$ Thus, while courts have required some support in the case law ${ }^{68}$ or regulations ${ }^{60}$ for the government's arguments, usually any contradictory precedent is enough to make an argument reasonable, ${ }^{61}$ as are conflicting regulations, ${ }^{62}$ or even a misreading of the legislative history. ${ }^{63}$ Similarly, while courts have found the government's arguments unreasonable if they have been repeatedly rejected by other courts, ${ }^{64}$ or are contrary to the agency's own

58. E.g., Ramos v. Haig, 716 F.2d 471, 472, 474 (7th Cir. 1983) (government substantially justified where INS cites two cases which "arguably support its legal position," despite district court finding of due process violation for detaining Cuban refugees for 15 months without a hearing); Kirkland v. Railroad Retirement Bd., 706 F.2d 99, 105 (2d Cir. 1983) (Board's position was not "so devoid of legal or factual support that a fee award is appropriate"); Gava v. United States, 699 F.2d 1367, 1370-71 (Fed. Cir. 1983) (government's litigation position was substantially justified where its arguments were "cogent" and it "cited several cases" in support of its arguments, despite lower court's finding on summary judgment that agency action was arbitrary and capricious).

59. See Hoang Ha v. Schweiker, 541 F. Supp. 711, 713 (N.D. Cal. 1982), rev'd on other grounds, 707 F.2d 1104 (9th Cir. 1983).

60. See NAACP v. Donovan, 554 F. Supp. 715, 717 (D.D.C. 1982).

61. See Donovan v. Miller Properties, Inc., 547 F. Supp. 785, 790 (M.D. La. 1982), affd, 711 F.2d 49 (5th Cir. 1983). While there is evidence that Congress intended that difficult cases of unsettled law be considered "reasonable," it is troubling that courts tend to find substantial justification where there is any uncertainty in the case law. For example, many courts allow any "genuine dispute," the term used in FED. R. Crv. P. 37, to defeat an award, see, e.g., Smith v. Schweiker, 563 F. Supp. 891, 892 (E.D.N.Y. 1982) (since Rule 37 is source of standard, if dispute is "genuine," losing party is "substantially justified," even in social security case resolved under lack of substantial evidence test), aff d without opinion, 729 F.2d 1442 (2d Cir. 1983); see also Trustees for Alaska v. Watt, 556 F. Supp. 171, 173 (D. Alaska 1983); however, this standard is lower than the "reasonableness" test Congress intended, see Wade v. Dole, No. 80 C 3072, slip op. (N.D. Ill. Dec. 19, 1983).

62. See Foley Constr. Co. v. U.S. Army Corps of Eng'rs, 716 F.2d 1202, 1206 (8th Cir. 1983), cert. denied, 104 S. Ct. 1908 (1984); see also Southern Oregon Citizens Against Toxic Sprays v. Watt, 556 F. Supp. 155, 157 (D. Or. 1983) (government was substantially justified in its arguments opposing injunctive suit where regulation was "convoluted" and difficult to interpret), modified sub nom., Southern Oregon Citizens Against Toxic Sprays v. Clark, 720 F.2d 1475 (9th Cir. 1983), cert. denied, 105 S. Ct. 446 (1984).

63. See Cinciarelli v. Reagan, 556 F. Supp. 99 (D.D.C. 1983), aff'd in part and rev'd in part, 729 F.2d 801 (D.C. Cir. 1984); see also Blitz v. Donovan, 740 F.2d 1241, 1247 (D.C. Cir. 1984) (government's litigation position found substantially justified where it "complied with sound canons of statutory construction, had some support in the legislative history, and contradicted no definitive congressional purpose").

64. See Underwood v. Pierce, 547 F. Supp. 256 (C.D. Cal. 1982) (where all nine courts addressing the issue had ruled against the government, its arguments were not substantially justified). 
practice, ${ }^{65}$ it may be reasonable to attempt to "reopen a closed question," or to invite the court to reconsider governing precedent. ${ }^{67}$

Courts have found it even more difficult to set limits on the range of arguments they will find acceptable under the second part of the substantial justification test, the "special circumstances" exception for "novel but credible" attempts to extend the law. ${ }^{88}$ While one court has stressed that such arguments must not only be novel but must also "merit the court's careful examination," often defeat an award. ${ }^{70}$ The breadth of this exception is particularly problematic because of the courts' tendency simply to merge the "novel but credible" concept into the "substantially justified" test, finding such arguments reasonable. ${ }^{71}$

\section{Evaluating Settlements}

Cases involving settlements provide another particularly illuminating example of the difficulty of giving any coherent meaning to "substantially justified." If the government's decision to settle were the only issue that the court examined, it would lead to a virtually automatic denial of fees in every settlement case, since the government would always be found to have acted reasonably; courts have found such a result to be clearly contrary to the Act's purposes. ${ }^{72}$ At the same time, however, in many settlement cases the information generated about the underlying action is not

65. See Bertrand v. United States, 562 F. Supp. 222, 224 (D. Or. 1983).

66. Wyandotte Sav. Bank v. NLRB, 682 F.2d 119, 120 (6th Cir. 1982) (Board's position that bargaining unit was appropriate was a "reasonable attempt to reopen a closed question," and was substantially justified despite contrary precedent in same circuit).

67. S \& H Riggers \& Erectors, Inc. v. O.S.H.R.C., 672 F.2d 426, 430-31 (5th Cir. 1982) (government's argument was substantially justified where it "presented an occasion for fresh consideration of [existing] precedents" in same circuit).

68. H.R. REP. No. 1418, supra note 5, at 11. The Civil Rights Attorneys Fee Awards Act of 1976 contains an identical provision, 42 U.S.C. $\$ 1988$ (1982). However, $\S 1988$ has been interpreted more narrowly. See Watkins, A Statutory Primer: Attorneys Fees Against the U.S. Under the Equal Access to Justice Act, 1983 ARk. L. Notes 82 (describing case law under $\S 1988$ ).

69. Nunes-Correia v. Haig, 543 F. Supp. 812, 820 (D.D.C. 1982) (the clause "does not create a different, less rigorous standard of review for all cases of first impression"; it "does not follow that because the government's argument was untested, it was necessarily worthy of credit").

70. See, e.g., Trustees for Alaska v. Watt, 556 F. Supp. 171, 173 (D. Alaska 1983) (government's litigation stance "can certainly not be characterized as frivolous" if pertinent statutory provision has not yet been interpreted); Midwest Research Inst. v. United States, 554 F. Supp. 1379, 1392 (W.D. Mo. 1983) (case presented novel issue and therefore met guidelines for "special circumstances"), affd, 744 F.2d 635 (8th Cir. 1984).

71. See, e.g., Hoang Ha v. Schweiker, 707 F.2d 1104, 1106-07 (9th Cir. 1983) (government's argument was novel but credible attempt to extend law, therefore government was substantially justified); S \& H Riggers \& Erectors, Inc. v. O.S.H.R.C., 672 F.2d 426, 430-31 (5th Cir. 1982).

72. Finding all settlements to be fee-exempt would be contrary to the legislative intent to include in its definition of "prevailing parties" those who prevail by favorable settlement. See, e.g., EDF v. Watt, 722 F.2d 1081, 1085 (2d Cir. 1983) ("If . . . by settling a case the government could automatically make its position 'substantially justified' and thereby avoid any fee liability, the statute would withdraw with one hand what it proferred with the other."). 
sufficient to enable the court to decide on any other basis. ${ }^{73}$ Thus, courts have sought factors by which to distinguish different settlements.

Some courts have relied on the amount of time taken to reach a settlement. However, this approach can raise the even more difficult problem of distinguishing reasonable and unreasonable time periods. ${ }^{74}$ For this reason, other courts have emphasized instead the timing of the settlement. They have characterized as reasonable those settlements occurring immediately after a complaint was filed, and unreasonable those occurring only after the government filed some opposition in court. ${ }^{75}$ Both distinctions are fairly arbitrary. Moreover, judgments about the reasonableness of settlements are even more problematic where courts have found the government to have been substantially justified in conceding an entire case, without even entering into settlement negotiations. ${ }^{76}$

\section{A Better Standard-Automatic Fee-Shifting}

The problems which have developed under the "substantially justified" standard thus reveal that it is inherently unsuited to creating an effective

73. See Citizens Coalitions for Block Grant Compliance v. City of Euclid, 537 F. Supp. 422,426 (N.D. Ohio 1982) (where there has been "no trial on the merits and no admission of fault in a consent decree or otherwise," such as in settlement cases, court has insufficient information about underlying action and must examine reasonableness of government's litigation position); see also Walton v. Lehman, 570 F. Supp. 490, 495 (E.D. Pa. 1983) (adopting same rationale in summary judgment case).

74. See EDF v. Watt, 722 F.2d 1081, 1086, 1089 (2d Cir. 1983) (majority found that sevenmonth settlement negotiation period "is not a short period" given narrow scope of issues and brevity of resulting stipulation, while dissent would have upheld lower court's determination that case was settled "shortly" after it was filed). Examining the duration of the settlement negotiations also presents the problem of determining which party caused the delay. See id. at 1086 (where all issues settled in private party's favor, excessive length of negotiation period supports inference of government delay).

75. See, e.g., Spencer, 712 F.2d at 555 n.58 ("[I]f the government does not immediately accede to the plaintiff's demand, but instead initially opposes his claims and then at some later stage ... surrenders, the United States will be liable for attorneys fees . . . ."); Watt, 722 F.2d at 1088 (Newman, J., dissenting) ("I would impose liability every time the settlement followed the assertion of a litigating position that was not substantially justified ...," but would not award fees "when the Government offers no courtroom opposition at all.").

76. In such cases, the government may be found to have a reasonable litigation position, based on the promptness of its concession, even where the private party obtained full relief, and the government never defended its action at all. See, e.g., Ashburn v. United States, 740 F.2d 843, 850 (11th Cir. 1984) (while district court found government not substantially justified where it "did not concede until almost eleven months after the plaintiffs filed their complaint," appellate court reversed, finding that the "Justice Department is entitled to the time reasonably necessary to receive and review the Service's files"); White v. United States, 740 F.2d 836, 842 (11th Cir. 1984) (government found substantially justified where it conceded issue three months after party raised it in complaint, reversing lower court). Such cases combine the difficulty of defining "reasonable" periods of time with the unfair results created by the court's refusal-or inability, given the lack of evidence-to examine the underlying action which forced the party to sue. Moreover, there are many ways in which a party may prevail against the government without a full trial on the merits, including obtaining dismissal of a complaint, entering into a consent judgment, or winning on summary judgment. See H.R. REP. No. 1418, supra note 5, at 11 ("The phrase 'prevailing party' should not be limited to a victor only after entry of a final judgment following a full trial on the merits."). 
fee incentive. At the same time, the cases cast doubt upon the original rationale for rejecting an automatic standard-fear of a chilling effect on legitimate government enforcement efforts. Therefore, upon reconsideration in 1985, Congress should replace the "substantially justified" standard with an automatic fee-shifting provision, which would simply provide that unless otherwise specified by statute, the court "shall award the reasonable fees and expenses of attorneys to a prevailing party other than the United States in any non-tort civil action brought by or against the United States."'77

\section{A. Automatic Fee-Shifting as the Optimal Fee Incentive}

If using fees to create an incentive to private suits challenging unreasonable governmental actions were the sole objective, an automatic standard would be preferable to the present standard in every respect. First, an indispensible attribute of any fee incentive is that a party must be able to judge at the outset of the litigation the likelihood of a fee award upon prevailing. Under the "substantially justified" standard, however, it is virtually impossible for parties to make this evaluation with any certainty. Not only is the law governing fee awards extremely unclear, but awards have no necessary relation to the strength of the party's claim. Thus, a party cannot calculate, based on the facts of his own case, the likelihood of a fee award if he prevails, ${ }^{78}$ nor are the most egregious cases of government abuse necessarily the most likely candidates for fee-shifting.

Under an automatic standard, awards would be certain for any qualified prevailing party. Moreover, by tying the fee award determination to the outcome of the case, an automatic standard would collapse the fee evaluation into an evaluation of the likelihood of prevailing; the decision whether to litigate, then, would be a single-, rather than two-tiered, analysis.

Second, it is important that the fee litigation not become a full second trial on the merits. ${ }^{79}$ Lengthy fee disputes detract from the effectiveness of

77. This provision is based upon the original Senate version of the Act. See supra note 19.

78. At present, in order for a party to judge the likelihood of his obtaining a fee award at the outset of a litigation, he must predict both what government behavior the court will examine and what definition it will apply. Moreover, even if the party feels, based on this analysis, that the agency action was so egregious that no court could find the government justified in defending the case, he still cannot predict whether the government will settle and thus possibly escape fee liability.

79. See Hensley v. Eckerhart, 103 S. Ct. 1933, 1943 (1983). 
any fee mechanism by adding significantly to the cost and delay of litigation. Under the present standard, however, the threat of an extensive second examination into the merits is quite real, since by its terms the standard specifically contemplates that the court reconsider the conduct at issue in the suit. ${ }^{80}$

Under an automatic standard, only the questions of the prevailing party and the amount of fees would be litigated. Not only would this standard preclude an intrusive second judicial examination into the propriety of the agency conduct, but it would limit the courts' consideration to issues on which a significant body of case law has already developed under other fee-shifting statutes. ${ }^{81}$ Eliminating the cost and delay of the fee litigation would, moreover, be as important as creating a fee incentive for the underlying litigation, since the disparity in resources between a private party and the government may deter the vindication of meritorious fee claims as well as of other rights. ${ }^{82}$

\section{B. Automatic Fee-Shifting Would Adequately Protect Enforcement Interests}

While recognizing that fulfilling the Act's purposes called for an automatic standard, Congress adopted the "substantially justified" standard in response to Justice Department objections that certain legitimate enforcement efforts would be chilled by automatic fee-shifting. However, the cases shed doubt on the premise of the Justice Department's argument, that enforcement efforts would indeed be chilled by the prospect of a fee

80. See The Awarding of Attorneys Fees in the Federal Courts: Hearings on S. 265 Before the Subcomm. on Courts, Civil Liberties, and the Admin. of Justice of the House Comm. on the Judiciary, 96th Cong., 2d Sess. 42 (1980) (statement of Alice Daniels, Ass't Attorney General, Dep't of Justice) (standard "invites a retrial of the merits"); see also S. REP. No. 586, supra note 18, at 24 (letter from Robert A. McConnell, Ass't Attorney General, Dep't of Justice) (objecting to defining "position" to include underlying action on ground that such a reading would generate a "potentially far lengthier proceeding").

81. Congress explicitly indicated that courts should rely on existing case law in determining whether a party has "prevailed." See H.R. REP. No. 1418, supra note 5, at 11 . Courts have also used existing standards in determining the amount of fees to be awarded. See Chee v. Schweiker, 563 F. Supp. 1362, 1365 (D. Ariz. 1983) (using 12 factor test to assess fee amount) (citing Kerr v. Screen Extras Guild, Inc., 526 F.2d 67, 90 (9th Cir. 1975), cert. denied, 425 U.S. 951 (1976)).

82. The question of whether fees are available for the fee litigation itself has resulted in the contorted consideration of whether the government's argument that it was "substantially justified," although ultimately found nonmeritorious in the fee litigation, is nevertheless itself "substantially justified," so as to require a denial of fees for that portion of the litigation. See Cinciarelli v. Reagan, 729 F. 2d 801, 809-10 (D.C. Cir. 1984) (noting the "Kafkaesque judicial nightmare" created by application of substantial justification test to fee litigation). Given that the same considerations apply to fee litigation as to other litigation with the government, and that the Act's purposes would be seriously jeopardized by disincentives to fee applications under the Act, there is a strong argument for making fee awards for successful fee litigation automatic, even if an automatic standard is rejected for the Act's central provision. See id. at 810 (adopting per se fee-shifting rule for fee litigation to avoid "infinite regression" of EAJA litigation). 
award. Government decisions to sue to clarify developing areas of law or resolve conflicts in regulations are often made as a matter of policy rather than on the facts of a particular case, ${ }^{83}$ as are its decisions to bring test cases. ${ }^{84}$ Thus it is not at all clear that the government's enforcement interests would be threatened in any significant way by the availability of fee awards. $^{85}$

Moreover, even if one accepts the possibility of such a chilling effect, only a limited range of enforcement interests can be protected under the standard without undermining the Act's basic purposes, and these can actually be well accommodated under an automatic standard.

\section{Narrowing the Range of Protected Enforcement Interests}

Exactly what the Justice Department meant when it referred to the legitimate enforcement efforts that would be chilled by an automatic standard is unclear. However, taking the argument on its face, Congress designed a standard that seems to contemplate two types of legitimate government enforcement efforts to be protected from fee-shifting. ${ }^{88}$ First, Congress anticipated that there would be cases involving unsettled or close legal questions, particularly in developing areas of law, in which the government could not be sure of winning but nevertheless had a legitimate interest in seeking a judicial resolution. ${ }^{87}$ Such close cases were to be included in those found reasonable under the "substantially justified" test. Second, Congress apparently also contemplated protection from fee-

83. In litigation under the Act, for example, the government has vigorously opposed every single fee application, see supra note 16, a practice which strongly suggests that the Justice Department's policy of opposition is not based on a careful evaluation of the merits of any particular fee application.

84. See Spencer, 712 F.2d at 559 ("[T]here is no good reason to suppose that fee-shifting [in cases in which the government challenges controlling precedent] will deter the government from bringing such test cases.") (emphasis in original).

85. See id. ("If the issue is important enough, government officials, who of course are not personally liable for the payment of fees, should not be dissuaded by the prospect of an award of fees to a private party's counsel."); Hearings, supra note 6, at 12 (statement of Sen. Nelson) (where the agency seeks to "expand its interpretation of the law in an uncharted area and the outcome is uncertain, ... it should not be deterred by the possibility that the individual or small business would receive attorney's fees"); Lempert, Few Claimants Win Fee Awards in Agency Actions, Legal Times, Apr. 25, 1983, at 5, col. 2 (where governmental parties are "policy-makers, not enforcement lawyers," often their "policy reasons for taking a certain position outweigh the legal considerations").

86. Since the legislative history does not explain what was meant by an automatic standard's failure to "account for the reasonable and legitimate exercise of governmental functions," H.R. REP. No. 1418, supra note 5, at 13-14, one must refer to the standard itself and to the brief Justice Department testimony to determine what Congress meant to include in "proper government enforcement efforts," id. at 14.

87. The Justice Department stressed that awarding fees in cases in which the law was unclear or there was a genuine factual dispute would have a "chilling effect" with serious consequences for developing areas of law. See supra note 22 . The reasonableness standard was meant to eliminate such cases from the Act's coverage. See H.R. REP. No. 1418, supra note 5, at 14. 
shifting for test cases-government efforts to change unfavorable precedents or reshape the law in new directions. Thus, under the "special circumstances" clause, "vigorous enforcement efforts" were also considered among those legitimate enforcement efforts to be protected from fee awards. ${ }^{88}$

However, in adopting this compromise "substantially justified" standard, Congress failed to appreciate that exempting certain enforcement efforts from fee-shifting is incompatible with the Act's basic purposes of encouraging private suits and discouraging agency abuses. In particular, as courts have recognized in reading the "special circumstances" clause restrictively, ${ }^{80}$ excluding government efforts to change case law seriously undermines the purpose of a fee incentive. If the government escapes fee liability in every test case, a private party will never know at the outset of litigation whether or not to expect a fee award, since it cannot predict what legal arguments the government will make. In fact, such an exception would exclude precisely those cases in which the party's expectation of prevailing was most legitimate, based on existing case law. ${ }^{90}$ Thus, although the differentiation is admittedly difficult, for the purpose of creating a fee incentive the concept of legitimate enforcement efforts must be limited to close cases, and the fee-shifting standard cannot include an exception for test cases.

Moreover, although Congress adopted the "substantially justified" standard in order to except close cases from fee-shifting, the Act's basic purposes require that certain types of close cases be included in fee-shifting. In particular, Congress wanted to discourage the government from litigating cases, especially prosecutions, where there was or should have been serious uncertainty on the government's part as to whether the law applied to the facts of the case at hand; such cases were prime examples of the administrative abuses Congress sought to correct in passing the Act. ${ }^{91}$

88. What Congress meant by "the novel but credible extensions and interpretations of the law that often underlie vigorous enforcement efforts," $i d$. at 11 , is not at all clear. However, the Justice Department testimony stressed the government's constitutional responsibility to enforce the law, and bringing test cases is clearly an important executive enforcement function. The government has thus argued that the "special circumstances" clause encompasses test cases. See S \& H Riggers \& Erectors, Inc. v. O.S.H.R.C., 672 F.2d 426, 430-31 (5th Cir. 1982) (government's attempt to "reopen a closed question" is a "novel but credible extension or interpretation of the law").

89. See Spencer, 712 F.2d at 559 n.72 ("the congressional committees pointedly did not refer to good faith efforts to seek changes in existing interpretations of the law") (emphasis in original).

90. For the same reason, the party's fee claim may be strongest in these cases as well. See id. at 559 ("[T]he more clearly established are the governing norms, and the more clearly they dictate a result in favor of the private litigant, the less 'justified' is it for the government to pursue or persist in litigation.").

91. Congress specifically intended that fee awards would force government agencies to carefully evaluate each case before proceeding, and "not to pursue those which are weak or tenuous." H.R. REP. No. 1418, supra note 5, at 14; see also Hearings, supra note 6, at 12 (statement of Sen. Nelson) ("II]n those situations where the Government agency goes ahead without a strong case against 
This suggests that the range of close cases that can be included in legitimate, fee-exempt enforcement efforts must be far narrower than Congress initially appreciated in designing the "substantially justified" standard. ${ }^{92}$

\section{Equivalent Protection of Enforcement Interests Under An Auto- matic Fee-Shifting Provision}

This limited range of legitimate enforcement interests would be afforded virtually the same protection under an automatic standard as under the "substantially justified" provision. The "substantial evidence" and "arbitrary and capricious" review standards discussed earlier are only two examples of the deferential standards that apply to review of agency action. ${ }^{93}$ Agency decisions not to promulgate rules are given even more deference, ${ }^{94}$ and many other agency actions are not reviewable at all, unless they amount to a constitutional violation or are directly violative of an express statutory provision. ${ }^{85}$ Thus, under most standards of review, a judicial reversal of an agency action carries a fair implication of government conduct below a certain level of reasonableness. ${ }^{96}$ By limiting fee-shifting

a business; or where it is proceeding carelessly . . . I would be very happy if the enactment of this legislation caused some chilling effect on Government regulatory efforts.").

92. The range of close cases that could be protected from fee-shifting without affecting the incentive might include cases of serious conflicts in regulations, genuine disputes of material fact, or areas of significant confusion in the case law. In these cases, the private party would be on notice, at the outset of litigation, that a fee award was unlikely. Thus, such cases would not disrupt the fee mechanism in the way that test cases would, nor would they be among those unreasonable enforcement efforts which Congress specifically meant to deter. However, this Note argues that the costs of making any exception to fee-shifting would far outweigh the benefits.

93. Such deferential review standards are applicable in a significant proportion of cases litigated against the government. For example, in social security cases, which form one-fifth of the government's civil caseload, Hearings, supra note 3 , at 50 , the applicable standard is the lack of substantial evidence test. Similarly, in contract cases, which form over one-tenth of the civil cases involving the United States, $i d$., the standard governing judicial relief for unsuccessful bidders is one of "clear illegality." See Foley v. U.S. Army Corps of Eng'rs, 716 F.2d 1202, 1205 (8th Cir. 1983), cert. denied, 104 S. Ct. 1908 (1984). Moreover, the standard governing the most significant cases-those involving rulemaking-requires "arbitrary and capricious" behavior for an agency action to be overturned. See supra notes 49-50.

94. As long as an agency adequately explains the facts and policy concerns behind its decision not to institute a rulemaking proceeding, and those facts and concerns have some basis in the record, a reviewing court will not overturn its judgment. Foley, 716 F.2d at 1205 (citing WWHT, Inc. v. FCC, 656 F.2d 807, 817 (D.C. Cir. 1981)).

95. Such cases are immune from review under the APA because "statutes preclude judicial review" or the "agency action is committed to agency discretion by law." 5 U.S.C. $\S 706(2)(A)$, (E) (1982). See, e.g., Stryker's Bay Neighborhood Council, Inc. v. Karlen, 444 U.S. 223, 227-28 (1980) (judicial review under NEPA limited to ascertaining that agency considered environmental consequences of its action).

96. See, e.g., Grand Boulevard Improvement Ass'n v. City of Chicago, 553 F. Supp. 1154, 1162 (N.D. Ill. 1982) (finding of arbitrary and capricious agency conduct has "already demonstrated that the underlying position of the government was unreasonable"). 
to prevailing parties, an automatic standard would still provide a significant level of protection for these narrowly defined, reasonable government enforcement efforts. ${ }^{97}$

Moreover, further protection for government enforcement interests would be provided in the determination of the amount of fees to be awarded. As with the "substantially justified" standard, fee awards would be limited to the claims on which the party actually prevailed, rather than the whole case. ${ }^{98}$ Courts have developed standards for calculating the amount of the fee award under similar statutory provisions, notably under the Civil Rights Acts, which allow fees to be assessed according to the strength of the prevailing party's case. ${ }^{92}$ Thus, the fee award could be reduced in. proportion to the "reasonableness" of the government's action. ${ }^{100}$

Finally, to the extent that some legitimate governmental enforcement interests receive less protection under an automatic standard, it is not a concern that should be given overriding weight. The damage to executive branch interests created by allowing some legitimate efforts to be assessed for fees would be far less than the detrimental effects of allowing any exception to a fee incentive. ${ }^{101}$ While a narrower fee-shifting standard than the "substantially justified" test could be designed without adopting an automatic standard, allowing an exception would be extremely costly in terms of both the clarity and certainty of the standard. In addition, an exception could easily become a new outlet into which the present litigation over the issue of substantial justification could be channelled, and thus might become an exception threatening to swallow up the rule. If the

97. It is true that deferential standards of review apply only in government defenses of agency decisions, and not in government prosecutions. However, since Congress was particularly concerned with deterring the government from bringing weak enforcement suits, the scope of what constitutes "reasonable," fee-exempt, prosecutions must be quite narrow.

98. Courts have interpreted the Act to require awards only for those independent claims on which the private party prevailed. See, e.g., Goldhaber v. Foley, 698 F.2d 193 (3rd Cir. 1983) (government should be charged only with that portion of expenses attributable to its unjustified position); Matthews v. United States, 713 F.2d 677, 683-84 (11th Cir. 1983) (plaintiff is entitled to attorney's fees allocable to claim on which she prevailed).

99. See Hensley v. Eckerhart, 103 S. Ct. 1933, 1943 (1983) (holding that "the extent of a plaintiff's success is a crucial factor in determining the proper amount of an award" under $\S 1988$, and that "the district court should award only that amount of fees which is reasonable in relation to the results obtained").

100. Since the questions of which claims the private party prevailed upon and what is the appropriate amount of fees would still have to be litigated under this standard, it would be automatic only in a very limited sense. Parties would still have to apply and prove their entitlement to fee awards. This would ensure that fee awards, although undoubtedly higher than the present figures, would not increase dramatically. In any case, the costs of the provision could rise significantly before they even approached the figures that Congress was willing to authorize. See supra note 18.

101. See Hearings, supra note 80 , at 17 (statement of Sen. Domenici) ("The few instances where [the party] shouldn't be entitled to compensation balanced on the side of pushing the agencies and the bureaucracy to be careful."). 
risk of deterring a few possibly meritorious government suits under an automatic standard is weighed against that of creating a less effective incentive under an alternative test, the serious social costs involved in allowing the government to litigate non-meritorious suits against parties with limited resources must be found to outweigh any minimal damage to government enforcement interests. ${ }^{102}$

\section{CONCLUSION}

The confused and inconsistent decisions which have resulted from the courts' attempts to apply the "substantially justified" standard across the broad range of cases covered by the Act indicate that it is not a standard well-suited to creating an incentive for private suits challenging unreasonable governmental actions. At the same time, they reveal that the fear of government abuses and deterrence of meritorious suits continues to be well founded. Therefore, Congress should enact a strengthened version of the Act, replacing the "substantially justified" standard with an automatic fee-shifting provision. Such a standard would serve the congressional purpose of creating a fee incentive far better, while also adequately accommodating government enforcement concerns.

102. In this context, attorney's fee awards should be regarded not as a punitive measure but as a necessary cost of ensuring the fair administration of the law. See Hearings, supra note 6, at 12 (statement of Sen. Nelson) ("Congress should make it clear in these cases that the possible costs of attorney's fees is a part of the cost of doing government business."). 